\title{
Antagonistic Effect on the Lethality of Earthworm (Eisenia Fetid L.) Being Exposed to Binary Mixtures of Metribuzin, Halosulfuron, and Flumioxazin
}

Elham Samadi Kalkhoran

University of Mohaghegh Ardabili

Mohammad Taghi Alebrahim ( $\nabla$ m.t.alebrahim@gmail.com )

University of Mohaghegh Ardabili

Mohammad Taghi Alebrahim

University of Mohaghegh Ardabili

Hamid Reza Mohammaddust Chamn Abad

University of Mohaghegh Ardabili

Jens Carl Streibig

University of Copenhagen

Ali Ghavidel

University of Mohaghegh Ardabili

\section{Research Article}

Keywords: Acute toxicity, Earthworm, Herbicide joint action, LC50, Concentration Addition

Posted Date: February 18th, 2021

DOI: https://doi.org/10.21203/rs.3.rs-204749/v1

License: (1) This work is licensed under a Creative Commons Attribution 4.0 International License.

Read Full License 


\section{Abstract}

Frequent use of herbicides might impose a risk for nontarget species, such as earthworms. The objective was to test the combined toxic effect of binary herbicide mixtures: metribuzin:halosulfuron and metribuzin: flumioxazin on a nontarget earthworm in two test systems. Two experiments on filter paper and two on artificial soil determined lethality and chronic toxicity on the earthworm. Results showed the flumioxazin had no high toxicity in contact filter paper test, with the lethal concentration $\left(\mathrm{LC}_{50}\right)$ of 153.10 $\mu \mathrm{g}$ a.i $\mathrm{cm}^{-2}$ at $48 \mathrm{~h}$. In the artificial soil test, flumioxazin $\mathrm{LC}_{10}$ was $0.65 \mathrm{mg} \mathrm{a} . \mathrm{kg}^{-1}$ on day 14 . Metribuzin showed high toxicity to earthworms in the filter paper test with $\mathrm{LC}_{50} 17.17 \mu \mathrm{g} \mathrm{a.i} \mathrm{cm} \mathrm{cm}^{-2}$ at $48 \mathrm{~h}$ but $\mathrm{LC}_{10}$ of metribuzin. Halosulfuron and metribuzin were highly toxic with $L_{C_{10}}$ value 0.24 and $0.47 \mathrm{mg} \mathrm{a} . \mathrm{kg}^{-1}$ on day 14. The herbicides' mixed effect showed in both test systems antagonistic effect, meaning that the mixtures retracted the herbicides' action in the earthworms relative to a Concentration Addition reference model. A chronic toxicity test showed that earthworm catalase was stimulated by metribuzin:halosulfuron (50:50\%) and metribuzin (100\%).

\section{Introduction}

Weed infestation reduces yield and product quality and increases production costs (Zarea and Karimi, 2012). Herbicides represent the highest load of active ingredients on the ground than any other pesticides (Travlos et al. 2017). Excessive and frequent use of herbicides either alone or in mixtures might effectively control weeds and nontarget plants outside the arable land. Also, soil-dwelling animals like earthworms might be affected even though the herbicide mode is not targeted animals (Zhang et al. 2017). Often less than $0.1 \%$ of an herbicide reaches the target plants, while the remaining is absorbed by be the crop or left on the soil or contaminating the environment, including water and air (Gill and Garg 2014).

Earthworms are important macroinvertebrates of soil fauna and make up more than $80 \%$ of terrestrial invertebrates' biomass. Earthworms have critical functions in soil structure, soil characteristics $(\mathrm{pH}$, organic matter, nitrogen, and granulometry), nutrient immobilization, nitrogen mineralization of organic matter, soil permeability, and microbial community activity (Kumar and Kumawat 2018).

Earthworms are used as test species to measure the biological effect of heavy metals and pesticide pollution in soil due to their high sensitivity to soil pollutions (Wang et al. 2012; Chen et al. 2018). The species Eisenia fetida is currently used in ecotoxicology (Hirano and Tamaae 2011). The species is easily raised and bred in the laboratory and, therefore, a common species in laboratory experiments. Finally, the use of the species is recommended in ecotoxicological studies by European Union (EU), Organisation for Economic Co-operation and Development (OECD), and U.S. Environmental Protection Agency (EPA) (Nahmani et al. 2007a, b; Correia and Moreira 2010). Many studies have recently published the effects of different pesticides on earthworms (Yasmin and D'Souza 2010; Pelosi et al. 2014). 
Herbicide mixtures are commonly used to control a weed flora on arable land. The pesticide mixtures have received a great deal of attention in recent decades, mainly their effect outside the arable land (Mehler et al. 2008; Ohlsson et al. 2010). The joint action of toxic compounds is generally classified into two groups, the Concentration Addition (CA) and Independent Action (IA) reference models. The two models are essentially covering various views in the joint action of compounds in an organism. This paper solely focuses on CA, which assumes that two compounds do not interfere with its others' action in an organism (Hewlett and Plackett, 1979; Cedergreen et al. 2008). It means we must know the relative potency (strength) between two herbicides. If the effect of binary mixtures diverts from the CA Isobole, the effect can be classified as antagonistic, additive, or synergistic, respectively. If a mixture follows the CA isobole, the pesticides do not affect each other's action (Wang et al., 2016). Stepić et al. (2013) used the $\mathrm{CA}$ reference model and isoboles to assess the ecological risks of insecticides in binary mixtures. They found that all three situations, additive action, synergism, and antagonism, were found for the various compounds.

Metribuzin, halosulfuron, and flumioxazin are used in potatoes (Alebrahim et al. 2012; Grichar et al. 2003; Hutchinson, 2007). Metribuzin [4-amino-6-tert-butyl-3-methylsulfanyl-1,2,4-triazin-5-one] (Sencor WP 70\%) belongs to triazine herbicides and is a photosystem II inhibitor. It is used in potato, tomato, soybean, and carrot (Alebrahim et al. 2012). The halosulfuron methyl (methyl 3-chloro-5-[(4,6-dimethoxypyrimidin-2-yl) carbamoylsulfamoyl]-1-methylpyrazole-4-carboxylate) belongs to the sulfonylureas and is an inhibitor of the enzyme acetolactate synthase (ALS) (Chand et al. 2014). Halosulfuron methyl is a selective and systemic herbicide (Vencill 2002). The flumioxazin (2-(7-fluoro-3-oxo-4-prop-2-ynyl-1,4-benzoxazin-6yl)-4,5,6,7-tetrahydroisoindole-1,3-dione) is a $\mathrm{N}$ - phenylphalimide (Mossler and Langeland, 2006) and it is an inhibitor of enzyme protoporphyrinogen oxidase (PPO or Protox) (Vasilakoglou et al. 2013).

Those herbicides can either be applied in mixtures to control many weed species or be sequentially applied. In either case, the compounds' joint action is of interest for agronomists and in ecotoxicology to unravel the joint action on nontarget species.

The aim was to evaluate the acute $\mathrm{LC}_{50}$ (Lethal Concentration that kills $50 \%$ of the test animals) and chronic toxicity (Catalase activity) of the herbicides either alone or in binary mixtures of metribuzin:halosulfuron and metribuzin: flumioxazin and illustrating any departure from an isobole. The reference model was the Concentration Addition (CA), also denoted the Additive Dose Model (ADM) (Streibig and Jensen 2000). Deviation of the mixtures from the straight-line CA isoboles was used to classify the toxicology of those mixtures on earthworm populations in soil. This study was repeated twice to make a certain conclusion of the mixtures deviation from the CA was consistent.

\section{Materials And Methods}

\subsection{Herbicides and earthworm}


Formulated metribuzin (Sencor, WP 70\%) was obtained from Bayer, Persian AG, Tehran, Iran, halosulfuron (Sempra, WG 75\%) from Nufarm company and flumioxazin (Pledge, WP 50\%) was from Sumitomo chemical company. The stock solutions and dilution series of metribuzin, halosulfuron, and flumioxazin were prepared, and the dilution series applied on the day of the experiments. The healthy adult grown earthworms, which weighed between 350 and $600 \mathrm{mg}$ with completely- developed clitella, were purchased from the Iran earthworm company. The earthworms were kept in the natural soil, combined with decayed cattle manure with $35 \%$ of moisture and maintained at room temperature $\left(20 \pm 1^{\circ} \mathrm{C}\right)$ for at least two weeks before being used in the experiments (OECD 1984).

\subsection{Filter paper test}

A filter paper test was accomplished based on OECD guidance (OECD, 1984). A filter paper was put in a 9 $\mathrm{cm}$ petri-dish, and doses of metribuzin, halosulfuron, and flumioxazin used alone were applied. The herbicides were dissolved in acetone and loaded on a filter paper ( $2 \mathrm{ml}$ solution per petri-dish). After the solvent evaporated, the filter paper received $2 \mathrm{ml}$ of distilled water, and ten earthworms were placed on the filter paper. Three Petri-dishes, every one containing 10 adult earthworms, were made use for each concentration. The concentrations of metribuzin were $0.156,0.312,0.625,1.25,2.5,3.5,5,7,10,14,28$, 56,112 and $224 \mu \mathrm{g}$ ai. $\mathrm{cm}^{-2}$, for halosulfuron $0.0156,0.0312,0.0625,0.125,0.250,0.500,1,2,4,8,16,32$, 64,128 and $256 \mu \mathrm{g}$ ai. $\mathrm{cm}^{-2}$, and for flumioxazin $0.0390,0.0780,0.156,0.312,0.625,1.25,2.50,5,10,20$, $40,160,320$ and $640 \mu \mathrm{g}$ ai. $\mathrm{cm}^{-2}$. The petri-dish was coated with a plastic lid with small holes to prevent the earthworms from escaping and kept in the dark at $20 \pm 1^{\circ} \mathrm{C}$ at $80-85 \%$ relative humidity. The mortality was recorded 24 and 48 hours after treatment. The test determined the concentration range of the herbicides with different concentrations that caused 0-100\% mortality of the earthworm for each herbicide. Two experiments were executed with seven concentrations of herbicides on filter paper to find an optimal dose-range to describe the mortality.

The relative potency of the individual herbicides at $L C_{50}$ detrermined the mixture ratios, so they were distributed evenly along the CA isobole (Gessner, 1995). The mixture ratios of (100:0), (10:90), (25:75), (50:50) and (0:100) for metribuzin:halosulfuron and for metribuzin:flumioxazin they were (100:0), (4:96), (10:90), (25:75) and (0:100). The dose-response curves experiment was independently repeated twice.

\subsection{Soil toxicity test}

An artificial soil consisted of $10 \%$ ground sphagnum peat $(<0.5 \mathrm{~mm}), 20 \%$ kaolin clay ( $>45 \%$ kaolinite), $70 \%$ quartz sand $(<0.2 \mathrm{~mm})$, and a small amount of calcium carbonate to adjust soil pH at $7.0 \pm 0.5$ (OECD 1984). The water content was adjusted to $35 \%$. About $1 \mathrm{~kg}$ of artificial soil mentioned above was added into $2 \mathrm{~L}$ pot. Three pots, each containing 10 adult earthworms, were used for each concentration. The earthworms were kept at room temperature $20 \pm 1^{\circ} \mathrm{C}$ at $35 \%$ of moisture for $24 \mathrm{~h}$ in the dark before the dose-response test. The desired amount of herbicide solutions was thoroughly mixed with the soil for at least $5 \mathrm{~min}$ to allow a homogeneous distribution of the herbicide. Exposure dose of metribuzin were $0.004,0.008,0.016,0.032,0.064,0.089,0.128,0.179,0.256,0.359,0.717,1.435,2.871,5.743 \mathrm{mg} \mathrm{a}^{\mathrm{i}} \mathrm{kg}^{-1}$; 
and for halosulfuron $0.0004,0.0008,0.0016,0.0032,0.0064,0.0128,0.0256,0.0512,0.102,0.205,0.410$, 0.820 and for flumioxazin $0.001,0.002,0.004,0.008,0.016,0.032,0.064,0.128,0.256,0.512,1.025,2.05$ $\mathrm{mg}$ a.i $\mathrm{kg}^{-1}$. The pots were loosely covered with polypropylene lids, with small holes for air exchange, to prevent the earthworms from escaping. The pots were incubated at $20 \pm 1^{\circ} \mathrm{C}$ for a $12: 12 \mathrm{~h}$ light-dark regime. The mortality was recorded on 1, 7 and 14 days after the treatment. Earthworms were exposed to different concentrations with three replications for each treatment to estimate the $\mathrm{LC}_{50}$ of each herbicide (OECD 1984). Two experiments were executed with seven concentrations of herbicides on filter paper to find an optimal dose-range to describe the mortality.

Like the filter paper test, the mixtures ratios were based upon the relative potencies of the individual herbicides applied alone. The mixtures were for metribuzin:halosulfuron (100:0), (44:56), (70:30), (88:12), (0:100) and for metribuzin:flumioxazinyhey they were )100:0), (4:96), (10:90), (26:74), (0:100). Therefore the mixture ratios were roughly evenly distributed along the CA isoboles (Streibig and Jensen 2000). The mixture experiment was independently repeated twice.

\subsection{Biochemical assays}

The experiment to study the catalase activity was arranged in a randomized complete block design with a factorial arrangement consisting of two factors in three replications. The first factor was type of herbicides, including metribuzin, halosulfuron, flumioxazin, metribuzin:halosulfuron (10:90)\%, metribuzin:halosulfuron $(25: 75) \%$, metribuzin:halosulfuron (50:50)\%, metribuzin:flumioxazin $(4: 96) \%$, metribuzin:flumioxazin (10:90)\%, metribuzin: flumioxazin (25:75)\%). The second factor was the different concentration of $\mathrm{LC}_{50}$ value of each herbicide, including control, $0.025 * \mathrm{LC}_{50}, 0.05 * \mathrm{LC}_{50}, 0.1 * \mathrm{LC}_{50}$, and $0.5^{\star} \mathrm{LC}_{50} \mu \mathrm{g}$ ai. $\mathrm{cm}^{-2}$.

The concentrations were based on $\mathrm{LC}_{50}$ value of filter paper tests on $24 \mathrm{~h}$. For individual toxicity, the concentrations of metribuzin were set as 0 (control), $0.025^{\star} \mathrm{LC}_{50}\left(0.85 \mu \mathrm{g}\right.$ ai. $\left.\mathrm{cm}^{-2}\right), 0.05^{\star} \mathrm{LC}_{50}(1.7 \mu \mathrm{g}$ ai. $\left.\mathrm{cm}^{-2}\right), 0.1 * \mathrm{LC}_{50}\left(3.4 \mu \mathrm{g}\right.$ ai. $\left.\mathrm{cm}^{-2}\right)$, and $0.5 * \mathrm{LC}_{50}\left(17 \mu \mathrm{g}\right.$ ai. $\left.\mathrm{cm}^{-2}\right)$, for halosulfuron they were $0.025^{\star} \mathrm{LC}_{50}$ $\left(1.32 \mu \mathrm{g}\right.$ ai. $\left.\mathrm{cm}^{-2}\right), 0.05^{\star} \mathrm{LC}_{50}\left(2.64 \mu \mathrm{g}\right.$ ai. $\left.\mathrm{cm}^{-2}\right), 0.1 * \mathrm{LC}_{50}\left(5.29 \mu \mathrm{g}\right.$ ai. $\left.\mathrm{cm}^{-2}\right)$, and $0.5 * \mathrm{LC}_{50}\left(26.47 \mu \mathrm{g}\right.$ ai. $\mathrm{cm}^{-}$ $\left.{ }^{2}\right)$. For flumioxazin they were $0.025^{\star} \mathrm{LC}_{50}\left(7.33 \mu \mathrm{g}\right.$ ai. $\left.\mathrm{cm}^{-2}\right), 0.05^{\star} \mathrm{LC}_{50}\left(14.66 \mu \mathrm{g}\right.$ ai. $\left.\mathrm{cm}^{-2}\right), 0.1 * \mathrm{LC}_{50}$ $\left(29.33 \mu \mathrm{g}\right.$ ai. $\left.\mathrm{cm}^{-2}\right)$, and $0.5^{\star} \mathrm{LC}_{50}\left(146.69 \mu \mathrm{g}\right.$ ai. $\left.\mathrm{cm}^{-2}\right)$. The concentrations of join action toxicity of metribuxin:halosulfuron and metribuzin:flumioxazin were at a ratio (1:1) (Chen at al. 2018) of $0.025 \mathrm{LC}_{50}$, $0.05 \mathrm{LC}_{50}, 0.1 \mathrm{LC}_{50}$, and $0.5 \mathrm{LC}_{50}\left(\mathrm{LC}_{50}\right.$ of Fig. 2,3 is used)

Before the catalase (CAT) activity experiment, a piece of filter paper was placed into a $9 \mathrm{~cm}$ Petri dish, and ten earthworms were placed on the Petri dish with moistened filter paper to purge their gut contents for each treatment. Petri dishes were maintained at $20 \pm 1^{\circ} \mathrm{C}$ in the dark for $24 \mathrm{~h}$. The desired amount of herbicides was dissolved in distilled water and added to another clean petri-dish with filter paper. Ten gutcleaned earthworms were transferred into a clean petri-dish. The earthworms were kept at $20 \pm 1{ }^{\circ} \mathrm{C}$ in dark for $48 \mathrm{~h}$. Whole earthworms were lysed (1\% Triton X-100 and phosphate buffer, $\mathrm{pH} 7.0)$. The 
homogenates centrifuged at $4{ }^{\circ} \mathrm{C}$ for $20 \mathrm{~min}$ at $9000 \mathrm{~g}$. For catalase activity determination, a sample containing $2.00 \mathrm{ml}$ enzyme solution or hemolysate and $1 \mathrm{ml} \mathrm{H}_{2} \mathrm{O}_{2}$ (Hydrogen peroxide $30 \mathrm{mM}$ ) used at $20^{\circ} \mathrm{C}$ (room temperature) against a blank containing $1 \mathrm{ml}$ phosphate buffer instead of the substrate and 2 $\mathrm{ml}$ enzyme solution or hemolysate. The reaction is started by the addition of $\mathrm{H}_{2} \mathrm{O}_{2}$. It is mixed well with a plastic paddle and measured the decrease in absorbance with ultraviolet-visible spectrophotometry for about $30 \mathrm{sec}$ and wavelength $240 \mathrm{~nm}$ (Aebi 1974).

For a time interval of $30 \mathrm{sec}$, the following relationship is obtained according to Eq. (1):

$$
\mathrm{K}=0.153\left(\log \frac{A 1}{A 2}\right)\left(\sec ^{-1}\right)
$$

where $\mathrm{K}$ is rate constant, $\mathrm{A} 1$ first absorbance and $\mathrm{A} 2$, second absorbance

A one-way analysis of variance (ANOVA) of catalase was performed to determine statistical differences among treatments followed by the Duncan's multiple range test (MRT) at a confidence level of 0.05 .

\subsection{Statistical analysis}

The dose-response data were analyzed using the R program (Version 3.6.1). of earthworms in response to herbicides is classical in toxicology. The binomial response, dead or alive, was assessed at various times during the experiments. The log-logistic regression was conducted to assess the acute toxicity of metribuzin, halosulfuron and flumioxazin, and metribuzin ratios:halosulfuron and metribuzin:flumioxazin. The add-on R package drc (Version 3.0.1) was used to fit the log-logistic curves and the drc function mixture to illustrate the deviation of mixtures from the straight line isobole of the CA. reference model (Ritz et al. 2015).

Data were subjected to non-linear regression analysis using a two parameters log-logistic model (Ritz et al. 2015):

$$
y=\frac{1}{1+\left(\frac{x}{L C_{50}}\right)^{b}}
$$

Where $y$ is the binomial response, dead or alive, for earthworm and the total number of earthworms in a petri dish or artificial soil, $x$ represents herbicide concentration $\left(\mu \mathrm{g}\right.$ ai. $\mathrm{cm}^{-2}$ or $\mathrm{mg}$ ai. $\left.\mathrm{kg}^{-1}\right)$ of any mixture ratios defined as the sum of the actual doses. It means we fitted a total of five dose response curves per experiment for the binary mixtures. The experimental design was a so-called ray design (Gessner 1995). $L C_{50}$ is the concentration ( $\mu \mathrm{g}$ ai. $\mathrm{cm}^{-2}$ or mg ai. $\mathrm{kg}^{-1}$ ) that reduces live earthworm number by $50 \%$, and $b$ is the slope of the curve around $\mathrm{LC}_{50}$. The dose-response fitted reasonably well to the data, and the isoboles of mixtures were referenced to the $\mathrm{CA}$ isobole. 
In an $L C_{50}$ isobologram (Figs 2, 3, 5, 6), the $X$ and $Y$ axes are the dose axes of each individual herbicide in a mixture, e.g., metribuzin:halosulfuron. Thus, if metribuzin is the dose of the $X$-axis and halosulfuron is the dose on the Y-axis, and the mixtures are plotted; likewise, the mixture points represented the isobole points. The graph points represent the combination of the two herbicides that are iso-effective for a given response $\left(\mathrm{LC}_{50}\right)$. The solid lines for each $\mathrm{LC}_{50}$ point are the confidence interval for the mixtures.

If the herbicides in a mixture do not interact, the points will form a straight-line relationship as indicated in Figs. 2, 3, 5, 6. When herbicides are less effective than expected they show antagonistic action, larger amounts of each herbicide are required to produce the same effect as that of the herbicides applied alone. if the joint action of the herbicides are following the straight CA line thir action would be additive.

\section{Results}

\subsection{Filter paper test}

The acute toxicities of individual herbicides on E. fetida from the contact filter paper test are shown in Fig. 1a-c. It small concentrations no or little effect on lethality. Table 1 shows the $\mathrm{LC}_{50}$ at 24 and 48 hours. Obviously, the $\mathrm{LC}_{50}$ declined between 24 and 48 hours. The results demonstrated that an increase in exposure time was a factor that increased the mortality in the filter paper test media (Table 1). The toxicity of herbicides was ranked as metribuzin> halosulfuron > flumioxazin (Table 1), and the ranking did not change between the time of measurement.

The binary mixture experiments demonstrated that the first experiment with metribuzin:halosulfuron and metribuzin:flumioxazin exhibited antagonistic effect at 24 and $48 \mathrm{~h}$ in filter paper test (Fig. 2a1-b2), and the same applied to the second experiment (Fig. 3a1-b2).

\subsection{Soil toxicity test}

The results demonstrated that an increase in exposure time was a factor that increased the mortality in the artificial soil tests media (Table 2). The toxicity of herbicides was ranked as metribuzin> halosulfuron $>$ flumioxazin (Table 2) and the ranking did not change between the time of measurement. The same applied to the artificial soil (Tabel 2) for the $\mathrm{LC}_{10}$ values in Table 2; the dose range in Fig. 4a-c was not covering the higher $L C$ levels, and consequently, the $\mathrm{LC}_{50}$ was not part of the observed mortality range.

For the artificial soil toxicity test, the $\mathrm{LC}_{50}$ isobologram in Fig. 5a1-b3 and Fig. 6a1-b3 showed the same picture in both experiments: the joint action of the compounds acted antagonistically in the relation to the CA reference model. It means the mixtures would require higher doses of the tested mixture to get the same toxicity $\left(\mathrm{LC}_{50}\right)$ as if the herbicides were applied singly. This intrinsic effect of the mixtures in the animals requires that we have to unravel the mode of action of the herbicides in the animals, a mode of action that can be completely different from that in plants. 
There was much more variation in the artificial soil test than in the filter paper test, irrespective of experiments, but the mixtures' antagonistic effect was still valid. The potencies of the herbicide between filter paper and artificial soil tests are not comparable. Apparently, the test animals were more sensitive to the herbicides in the filter paper. The reason may come back to the point whenever doses and the living environment of the earthworms were very different.

\subsection{Influence of herbicides individually and combined on the catalase enzyme activity}

The results showed that concentration of herbicides on the base of $\mathrm{LC}_{50}$ had not significant differences; but the type of herbicide had significant difference on catalase activity $(P<0.05)$. The changes in catalase activity were described in Fig. 7. The catalase activity was significantly different as compared to the control among herbicides. The stimulation effect of Metribuzin:halosulfuron (50:50\%) and Metribuzin (100:0\%) on earthworm were longer than other herbicides.

\section{Discussion}

Mortality of Eisenia fetida is typically used in studying chemical toxicity compounds on earthworms (lordache and Borza 2011; Pelosi et al. 2014). The contact filter paper test is a fast, simple, and inexpensive test as a screening method for assessing relative toxicity (Wang et al. 2012).

The herbicides are designed to kill green plants, and therefore, the sites and modes of action are well known. When it comes to the site and mode of action in animals, the cause and effect relationship between mortality and specific site of action becomes more uncertain and needs to be further investigated. The increase of dose and exposure time increased the mortality in filter paper and artificial soil tests. For metribuzin, halosulfuron and flumioxazin, $100 \%$ mortality were observed a few hours after exposure on filter paper (Table 1 and Fig. $1 \mathrm{a}-\mathrm{c}$ ). The $\mathrm{LC}_{50}$ of metribuzin obtained from the contact filter paper test demonstrated that metribuzin was highly toxic to the earthworms while flumioxazin had low toxicity (Fig. 1a-c). The toxicity order in filter paper tests was metribuzin $>$ halosulfuron $>$ flumioxazin at 24 and $48 \mathrm{~h}$ after treatment (Table 1). Earthworm mortality by the presence of metribuzin may be caused by increased mucous secretion to a high concentration. The earthworms exposed to metribuzin also exhibited surface wounds and extrusion of coelomic fluid. It caused bloody lesions on the posterior part of the body and ultimately death. Fragmentation of the body was also observed because of exposure to metribuzin.

Metribuzin and halosulfuron had relatively larger toxicity than had flumioxazin. Perhaps mortality was related to an earthworm strategy for decreasing food consumption to avoid the toxins. This strategy is used for both heavy metals (Burrows and Edwards 2002) and pesticides (Wang et al. 2012). Soil ingestion and dermal absorption are the most crucial uptake paths of soil contaminants by earthworms. Earthworms can absorb and accumulate pollutants in their body tissues through the skin and digestive system (Shan et al. 2014). It should also be noted that increasing mortality might be correlated with the high persistence of metribuzin and halosufuron in soil or to the slow degradation in the earthworms and, 
subsequently, less elimination of the metabolites. Researches have proved that flumioxazin has a soil half-life between 11.9 and 17.5 days (Vencill 2002). Obviously, so small half-life might have an influence on the toxicity of the compound in particularly the artificial soil experiment.

Most of the herbicides residues were found in the upper $5 \mathrm{~cm}$ of the profile (Hyzak and Zimdahl 1974) while in the study of Hernandez et al. (1998) metribuzin was mobile in soil, as are ALS inhibitors. The results also indicated the low toxicity of flumioxazin in filter paper and artificial soil tests and could be attributed to the rapid elimination in the animals. Travlos et al. (2017) investigated the soil toxicity bioassays of benfluralin, metribuzin and propyzamide on the survival of E. fetida. They reported that the highest mortality was found after the treatment with double the recommended field rate of metribuzin (1500 g ai. ha-1 ${ }^{-1}$ at 3 weeks after treatment. In general, Kukta (1992) reported that the herbicides with $\mathrm{LC}_{50}$ value higher than $1000 \mathrm{mg}$ ai. $\mathrm{kg}^{-1}$ were noxious to earthworms.

Binary mixture effects can be classified as additive, synergistic, or antagonistic by using the CA as a reference model. Detracted action, also denoted antagonistic action is rather consistent in the experiments done here. It means that to obtain the same effect level (e.g., $\mathrm{LC}_{50}$ ) one needs a higher concentration of the mixture than that of the individual compounds applied singly. The opposite effect is the enhancement of the action at a specific $\mathrm{LC}_{\mathrm{x}}$ level, also denoted the synergistic effect. The results in our experiments clearly showed that the herbicide mixtures all acted antagonistically in two independent experiments. It means that the mixtures would require higher doses of the tested mixture to get the same toxicity (LC50) as if the herbicides were applied singly (Figs. 2, 3, 5, 6). This intrinsic effect of the animals' mixtures requires that we unravel the mode of action of the herbicides in the animals, a mode of action that can be completely different from that in plants. Sulfonylureas seem to be the most harmful herbicide pesticide families to earthworms (Pelosi et al. 2014).

Our results of the filter paper test are in line with the artificial soil test of individual and combined herbicides toxicity and confirmed the work by Stepić et al. (2013). According to some researchers, it is indicated that the laboratory test results cannot be extrapolated simply to field circumstances (Lowe and Butt 2007; Svendsen and Weeks 1997). However, in other cases, the field and laboratory outcomes are comparable (Heimbach 1984; Culy and Berry 1995; Holmstrup 2000). The complementarity between field investigations and laboratory tests is a perpetual discussion in the literature. When introducing, say, various mixtures, one needs both methods, as noted by Svendsen et al. (2005).

Herbicides can also alter enzyme activities. Enzymes play a vital role in neurocholinergic transportation and cell stability by hindering the toxic effect of chemicals (Mekhalia et al. 2016). The results of this study demonstrated that all herbicides were different from the control treatments in earthworm stimulation for catalase enzyme activity (Fig. 7). The maximum catalase enzyme activity was in metribuzin:halosulfuron (50:50\%) and metribuzin (100:0\%). Our study demonstrated that single metribuzin and halosulfuron are very toxic to earthworms in filter paper and artificial soil tests. The results in our experiments clearly showed that the herbicide mixtures all acted antagonistically in two independent experiments repeated twice in time, whether the mortality was assessed 24 or $48 \mathrm{~h}$ after the 
initiation of the experiments on filter paper. It means the joint action of the mixtures retracts their mutual effect in the earthworms.

\section{Declarations}

\section{Data availability}

Data are available by contacting ESK (samadielham@uma.ac.ir).

\section{Code availability}

The used R code is available by contacting ESK (samadielham@uma.ac.ir).

Acknowledgements This work was supported by the Faculty of Agriculture and Natural Resources, University of Mohaghegh Ardabili, Iran for financial support. The authors are grateful for the valuable comments of Roozbeh Zangoueinejad on earlier drafts of this paper.

Funding The work was financed by the Ph.D. scholarship program of the University of Mohaghegh Ardabili, Iran; also this research received grant from Mohammad Taghi Alebrahim.

Author contributions Mohammad Taghi Alebrahim conceived the ideas as a supervisor. Elham Samadi Kalkhoran assembled the data, analyzed the data with help from Jens Carl Streibig. Ali Ghavidel helped to interpret the data. Hamid Reza Mohammaddust Chaman Abad discussed about relationships between applying herbicide and environment. Elham Samadi Kalkhoran wrote the manuscript. Jens Carl Streibig, Mohammad Taghi Alebrahim and Ali Ghavidel edited the manuscript. All authors improved and approved the manuscript.

\section{Compliance with ethical standards}

Conflict of interest The authors declare that they have no conflict of interest.

Consent to participate The authors declare that they have no known competing financial interests or personal relationships that could have appeared to influence the work reported in this paper.

Consent to publish Informed consent was obtained from all individual participants included in the study.

Ethical approval This article does not contain any studies with human participants or animals performed by any of the authors.

Informed consent Informed consent was obtained from all individual participants included in the study.

Publisher's note Springer Nature remains neutral with regard to jurisdictional claims in published maps and institutional affiliations. 


\section{References}

Aebi H, Wyss SR, Scherz B, Skvaril F (1974). Heterogeneity of erythrocyte catalase II. Isolation and characterization of normal and variant erythrocyte catalase and their subunits. Eur J Biochem 48(1): 137-145. https://doi.org/10.1111/j.1432-1033.1974.tb03751.x

Alebrahim MT, Rashed Mohassel MH, Wilkakson S, Baghestani MA, Ghorbani R (2012). Evaluatin of 6 unregistered herbicides efficacy in iran potato fields and herbicide relation to cytochromes P450 monooxygenase enzyme. Ph.D. Thesis. Ferdowsi. University of Mashhad, Iran. (In Persian with English summary).

Burrows LA, Edwards CA (2002). The use of integrated soil microcosms to predict effects of pesticides on soil ecosystems. European J of Soil Biol 38 (3-4): 245-249. https://doi.org/10.1016/S11645563(02)01153-6

Cedergreen N, Christensen AM, Kamper A, Kudsk P, Mathiassen SK, Streibig JC, Sørensen H (2008). A review of independent action compared to concentration addition as reference models for mixtures of compounds with different molecular target sites, Environ Toxi and Chem 27(7): 1621-32. https://doi.org/ 10.1897/07-474.1

Chand M, Singh S, Bir D, Singh N, Kumar V (2014). Halosulfuron Methyl: A New post emergence herbicide in India for effective control of Cyperus rotundus in sugarcane and its residual effects on the succeeding crops. Sugar Tech. https://doi.org/10.1007/s12355-013-0263-4

Chen J, Saleem M, Wang C, Liang W, Zhang Q (2018). Individual and combined effects of herbicide tribenuron-methyl and fungicide tebuconazole on soil earthworm Eisenia fetida. Sci Rep 8: 2967. https://doi.org/10.1038/s41598-018-21288-y

Correia FV, Moreira JC (2010). Effects of Glyphosate and 2,4-D on Earthworms (Eisenia fetida) in Laboratory Tests. Bull Environ Contam Toxico. 85: 264-268. https://doi.org/ 10.1007/s00128-010-00897

Culy MD, Berry EC (1995). Toxicity of soil-applied granular insecticides to earthworm populations in cornfields. Down to Earth. 50: 20-25.

Gessner PK (1995). Isobolographic analysis of interactions: an update on applications and utility. Toxicology 105 (1995) 161-179

Gill HK, Garg H (2014). Pesticides - Toxic Aspects. Chapter 8: Pesticides. Environmental Impacts and Management Strategies.

Grichar WJ, Besler BA, Brewer KD (2003). Purple Nutsedge Control and Potato (Solanum tuberosum) Tolerance to Sulfentrazone and Halosulfuron. Weed Technol. 17:485-490. http://dx.doi.org/10.1614/WT02-045 
Heimbach $\mathrm{F}$ (1984). Correlations between three methods for determining the toxicity of chemicals to earthworms. Pestic Sci 15: 605- 611. https://doi.org/10.1002/ps.2780150612

Hernandez F, Beltran J, Forcada M, Lopez F, Morell I (1998). Experimental approach for pesticide mobility studies in the unsaturated zone. Int $\mathrm{J}$ of Environ Anal Chem 71: 87-103.

https://doi.org/10.1080/03067319808032619

Hewlett PS, Plackett RL (1979). An introduction to the interpretation of quantal responses in biology. Edward Arnold, London.

Hirano T, Tamae K (2011). Earthworms and Soil Pollutants. Sens (Basel) 11(12): 11157-11167. https://doi.org/10.3390/s111211157.

Holmstrup M (2000). Field assessment of toxic effects on reproduction in the earthworms Aporrectodea longa and Aporrectodea rosea. Environ Toxicol Chem 19: 1781-1787.

https://doi.org/10.1002/etc.5620190711

Hutchinson PJS. (2007). A comparison of flumioxazin and rimsulfuron tank mixtures for weed control in potato. Weed Technol. 21:1023-1028

Hyzak DL, Zimdahl RL (1974). Rate of degradation of metribuzin and two analogs in soil. Weed Sci 22: 75-79. https://doi.org/10.1017/S0043174500036560

Iordache M, Borza I (2011). Study of the acute toxicity of some pesticides on earthworms Eisenia fetida (Savigny, 1826). Res J of Agri Sci 43 (4): 95-100. https://doi.org/46989761

Kukta CA (1992). laboratory test on sublethal effects of pesticides on Eisenia fetida," in Ecotoxicology of Earthworms, H. Becker, P. J. Edwards, P.W. Greig-Smith, and F. Heimbach, Eds., pp. 55-62, Intersept Press, Andover, Hants.

Kumar K, Kumawat P (2018). A review of the effect of herbicides on the earthworms. Int $\mathrm{J}$ of Zool Stud 3(2): 120-125.

Lowe CN, Butt KR (2007). Earthworm culture, maintenance and species selection in chronic ecotoxicological studies: a critical review. Eur J Soil Biol 43: S281-S288.

https://doi.org/10.1016/j.ejsobi.2007.08.028

Mehler WT, Schuler LJ, Lydy MJ (2008). Examining the joint toxicity of chlorpyrifos and atrazine in the aquatic species: Lepomis macrochirus, Pimephales promelas and Chironomus tentans. Environ Pollut 152 (1): 217-224. https://doi: 10.1016/j.envpol.2007.04.028

Mekhalia MN, Tine S, Menasria T, Amieur H, Salhi H (2016). In Vitro Biomarker R.K. Tiwari et al. 2016. 121 Responses of Earthworm Lumbricus terrestris Exposed to Herbicide Sekator and Phosphate Fertilizer. Water Air and Soil Pollut 2016: 227:15. https:// doi: 10.1007/s11270-015-2712-z 
Mossler MA, Langeland KA (2006). Florida crop/pest management profile: aquatic weeds. University of Florida IFAS Extension. http://edis.ifas.ufl.edu/pdffiles/PI/PI17500.pdf. Accessed Jan. 8, 2008.

Nahmani J, Hodson ME, Black S (2007a). Effects of metals on life cycle parameters of the earthworm Eisenia fetida exposed to field contaminated, metal-polluted soils. Environ Pollut 149: 44-58. https://doi.org/10.1016/j.envpol.2006.12.018

Nahmani J, Hodson ME, Black SA (2007b). Review of studies performed to assess metal uptake by earthworms. Environ Pollut 145 (2): 402-424.

OECD (1984). OECD Guideline for Testing of Chemicals, Earthworm Acute Toxicity. OECD, Paris, France. No. 207. http://www.oecd. org/chemicalsafety/risk-assessment/1948293.pdf.

Ohlsson A, Cedergreen N, Oskarsson A, Ulleras E (2010). Mixture effects of imidazole fungicides on cortisol and aldosterone secretion in human adrenocortical H295R cells. Toxicol 275 (3): 21-28. https://doi.org/10.1016/j.tox.2010.05.013 (2010).

Pelosi C, Barot S, Capowiez Y, Hedde M, Vandenbulcke F (2014). Pesticides and earthworms. A review. Agron for Sustain Dev 34: 199-228.

Ritz C, Baty F, Streibig JC, Gerhard D (2015). Dose-Response Analysis Using R. Plos One 10(12): 0146021. https://doi.org/10.1371/journal.pone.0146021

Shan J, Wang Y, Wang L, Yan X, Ji R (2014). Effects of the geophagous earthworm Metaphire guillelmi on sorption, mineralization, and bound-residue formation of 4-nonylphenol in an agricultural soil. Environ Pollut 189: 202-207. https://doi.org/ 10.1016/j.envpol.2014.03.007

Stenrød M, Perceval J, Benoit P, Almvik M, Bolli RI, Eklo OM, Sveistrup TE, Kværner J (2008). Cold climatic conditions: Effects on bioavailability and leaching of the mobile pesticide metribuzin in a silt loam soil in Norway. Cold Reg Sci Technol 53 (1): 4-15. https://doi.org/ 10.1016/j.coldregions.2007.06.007

Stepić S, Hackenberger BK, Velki M, Lončarić Ž, Hackenberger DK (2013). Effects of individual and binary-combined commercial insecticides endosulfan, temephos, malathion and pirimiphos-methyl on biomarker responses in earthworm Eisenia andrei. Environ Toxicol and Pharmacol 36 (2): 715-723. https://doi.org/ 10.1016/j.etap.2013.06.011

Streibig JC, Jensen JE (2000). Action of herbicides in mixtures. In: Herbicides and their Mechanisms of Action (eds AH Cobb\& RC Kirkwood), 153-180. Sheffield Academic Press, Sheffield.

Svendsen C, Weeks JM (1997). A simple low-cost field mesocosm for ecotoxicological studies on earthworms. Comp Biochem Physiol Cpharmacol Toxicol Endocrinol 117: 31-40. https://doi.org/10.1016/S0742-8413(97)85596-X 
Svendsen TS, Hansen PE, Sommer C, Martinussen T, Gronvold J, Holter P (2005). Life history characteristics of Lumbricus terrestris and effects of the veterinary antiparasitic compounds ivermectin and fenbendazole. Soil Biol Biochem 37: 927-936. https://doi.org/10.1016/j.soilbio.2004.10.014

Travlos IS, Gkotsi T, Roussis I, Kontopoulou CK, Kakabouki I, Bilalis DJ (2017). Effects of the herbicides benfluralin, metribuzin and propyzamide on the survival and weight of earthworms (Octodrilus complanatus). Plant Soil and Environ 63(3): 117-124. https://doi.org/10.17221/811/2016-PSE

Vasilakoglou I, Dhima K, Paschalidis K, Gatsis T, Zacharis K, Galanis M (2013). Field bindweed (Convolvulus arvensis L.) and redroot pigweed (Amaranthus retroflexus L.) control in potato by pre- or post-emergence applied flumioxazin and sulfosulfuron. Chilean J of Agri Res 73(1): 24-30. http://dx.doi.org/10.4067/S0718-58392013000100004

Vencill WK (2002). Herbicide Handbook. 8th ed. Lawrence, KS: Weed Science Society of America. Pp. 477.

Wang JH, Zhu LS, Liu W, Wang J, Xie H (2012). Biochemical responses of earthworm (Eisenia fetida) to the pesticides chlorpyrifos and fenvalerate. Toxicol Mechanisms and Methods 22 (3): 236-241. https://doi.org/10.3109/15376516.2011.640718

Wang Y, An X, Shen W, Chen L, Jiang J, Wang Q, Cai L (2016). Individual and combined toxic effects of herbicide atrazine and three insecticides on the earthworm, Eisenia fetid. Ecotoxicol 2016. https://doi.org/10.1007/s10646-016-1656-4

Yasmin SH, D'Souza D (2010). Effects of pesticides on the growth and reproduction of earthworm: A review. Applied and Environ Soil Sci. 9 Pages. https://doi.org/10.1155/2010/678360

Zarea MJ, Karimi N (2012). Effect of herbicides on earthworms. Dyn Soil Dyn Plant 6 (1): 5-13.

Zhang Q, Saleem M, Wang C (2017). Probiotic strain Stenotrophomonas acidaminiphila BJ1 degrades and reduces chlorothalonil toxicity to soil enzymes, microbial communities and plant roots. AMB Expr. 7, 227. https://doi.org/10.1186/s13568-017-0530-y

\section{Tables}

Table 1 Estimated sigmoidal parameters for metribuzin, halosulfuron, and flumioxazin at $24 \mathrm{~h}$ and $48 \mathrm{~h}$ in filter paper test. Standard errors in parantheses 


\begin{tabular}{|ll|}
\hline \multicolumn{2}{|c|}{$24 \mathrm{~h}$} \\
\hline $\mathrm{LC}_{50}\left(\mu \mathrm{g}\right.$ ai. $\left.\mathrm{cm}^{-2}\right)$ & Herbicide \\
\hline $34.00(2.23)$ & MET \\
\hline $52.95(9.58)$ & HAL \\
\hline $293.38(47.89)$ & FLO \\
\hline $48 \mathrm{~h}$ & \\
\hline $17.17(1.17)$ & MET \\
\hline $52.95(9.58)$ & HAL \\
\hline $153.10(16.97)$ & FLO \\
\hline
\end{tabular}

Table 2 Estimated sigmoidal parameters for metribuzin, halosulfuron, and flumioxazin at 1 day, 7 days, and 14 days in artificial soil. Standard errors in parentheses

\begin{tabular}{|ll|}
\hline \multicolumn{2}{|c|}{1 day } \\
\hline $\mathrm{LC}_{10}(\mathrm{mg}$ a.i $/ \mathrm{kg})$ & Herbicide \\
\hline $0.97(0.28)$ & MET \\
\hline $1.02(0.54)$ & HAL \\
\hline $2.13(1.27)$ & FLO \\
\hline 7 day & \\
\hline $0.43(0.10)$ & MET \\
\hline $0.57(0.16)$ & HAL \\
\hline $1.04(0.35)$ & FLO \\
\hline 14 day & \\
\hline $0.24(0.06)$ & MET \\
\hline $0.47(0.10)$ & HAL \\
\hline $0.65(0.31)$ & FLO \\
\hline
\end{tabular}

Figures 
a

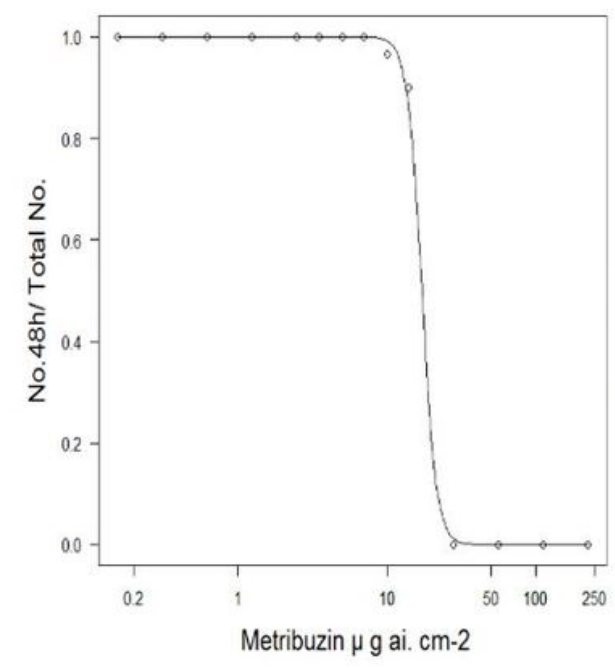

$\mathrm{b}$

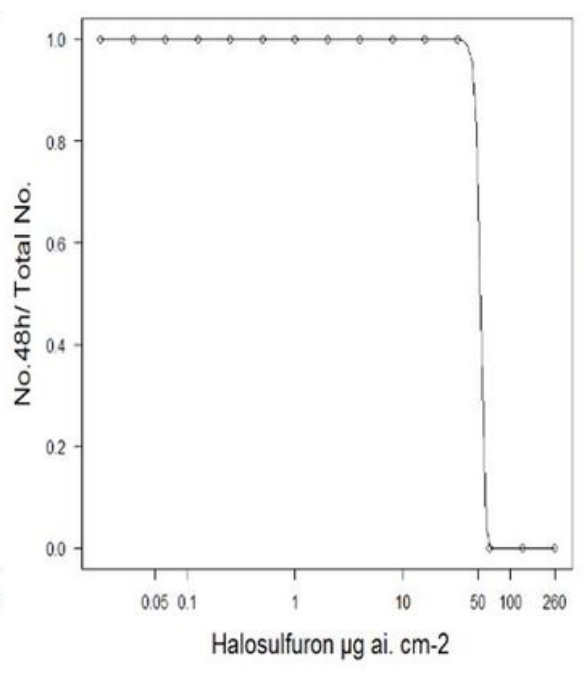

c

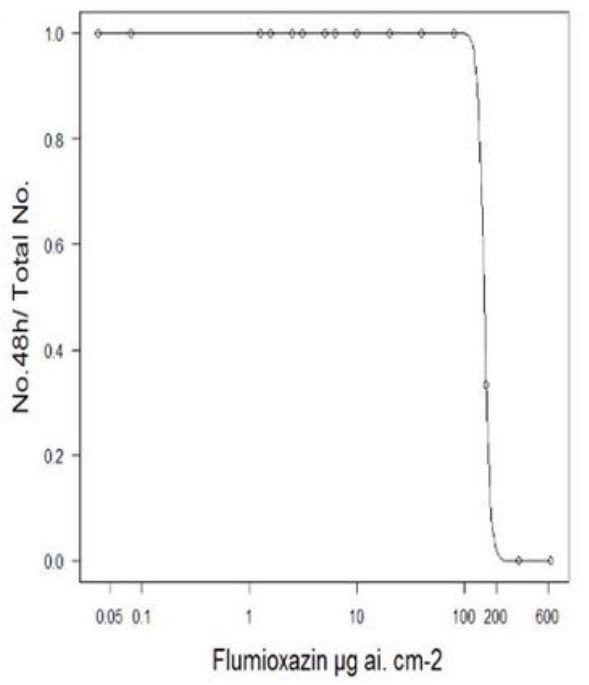

\section{Figure 1}

The effect of metribuzin (a), halosulfuron (b) and flumioxazin (c) on earthworm mortality at $48 \mathrm{~h}$ in filter paper test 


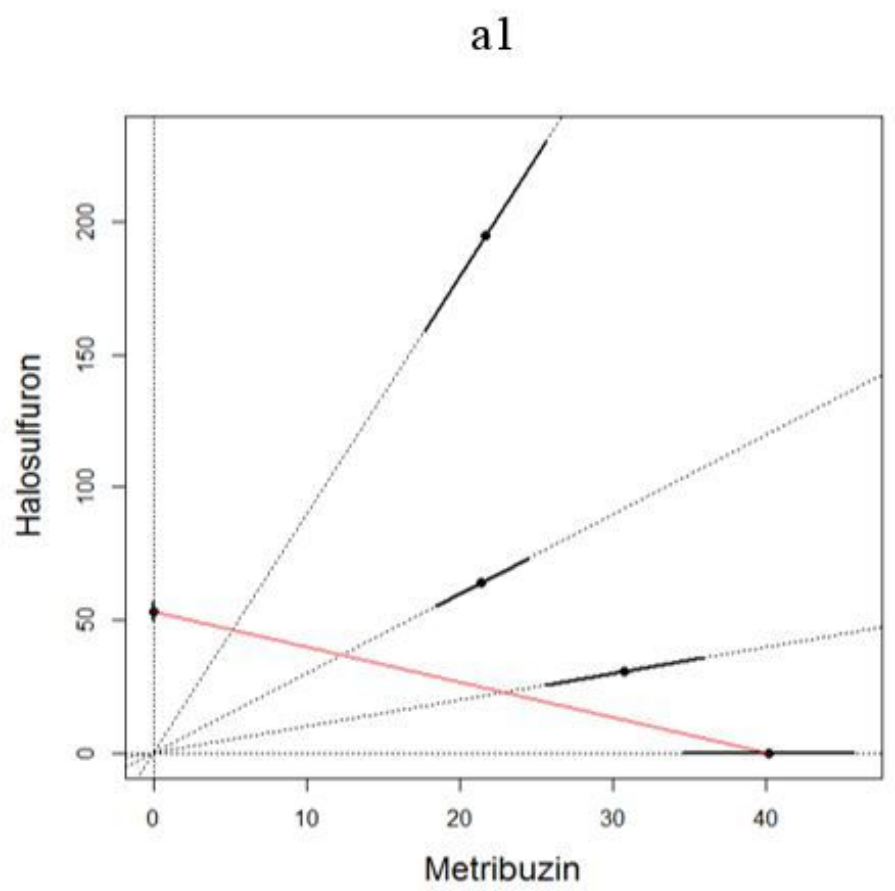

b1

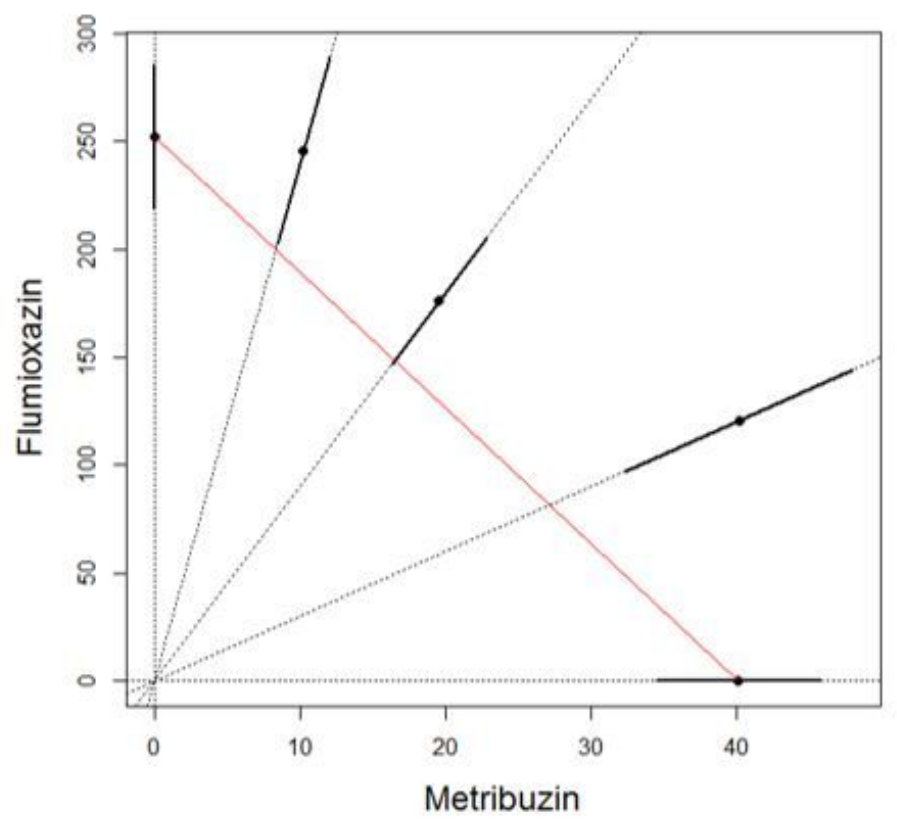

a2

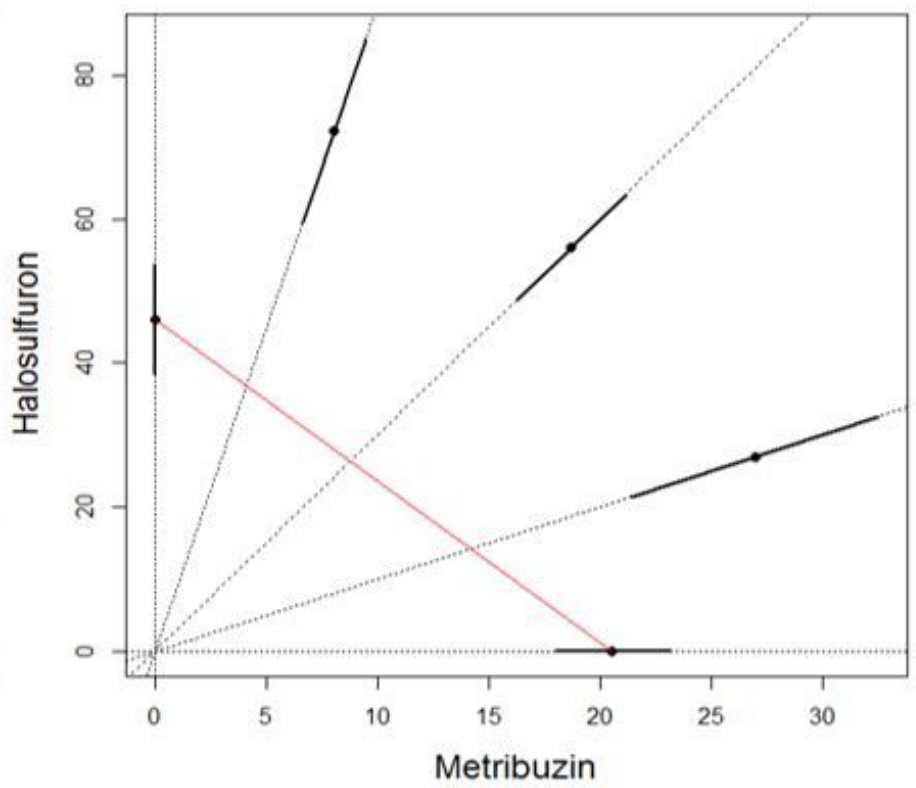

b2

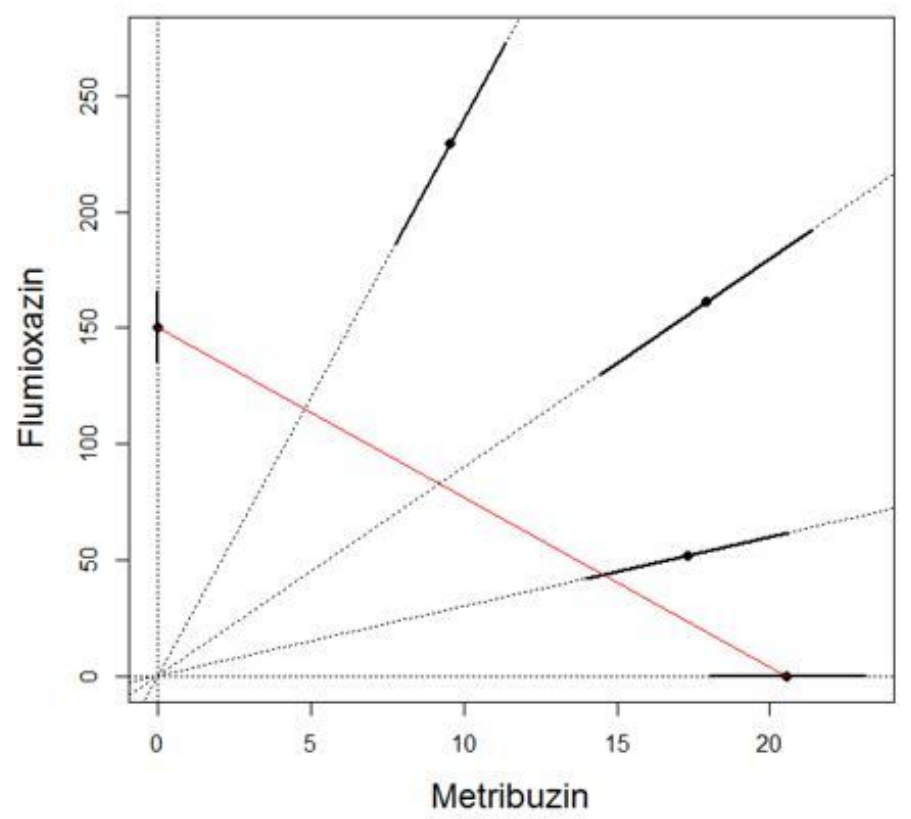

Figure 2

LC50 isobologram showing the toxicological interactions of metribuzin:halosulfuron (a) and metribuzin:flumioxain (b) for a mortality rate of Eisenia fetida in first experiment of filterpaper test at $24(1)$ and $48 \mathrm{~h}(2)$. The straight line of isobologram indicates additivity. The lines around the mixture points are $95 \%$ confidence intervals. 
a1

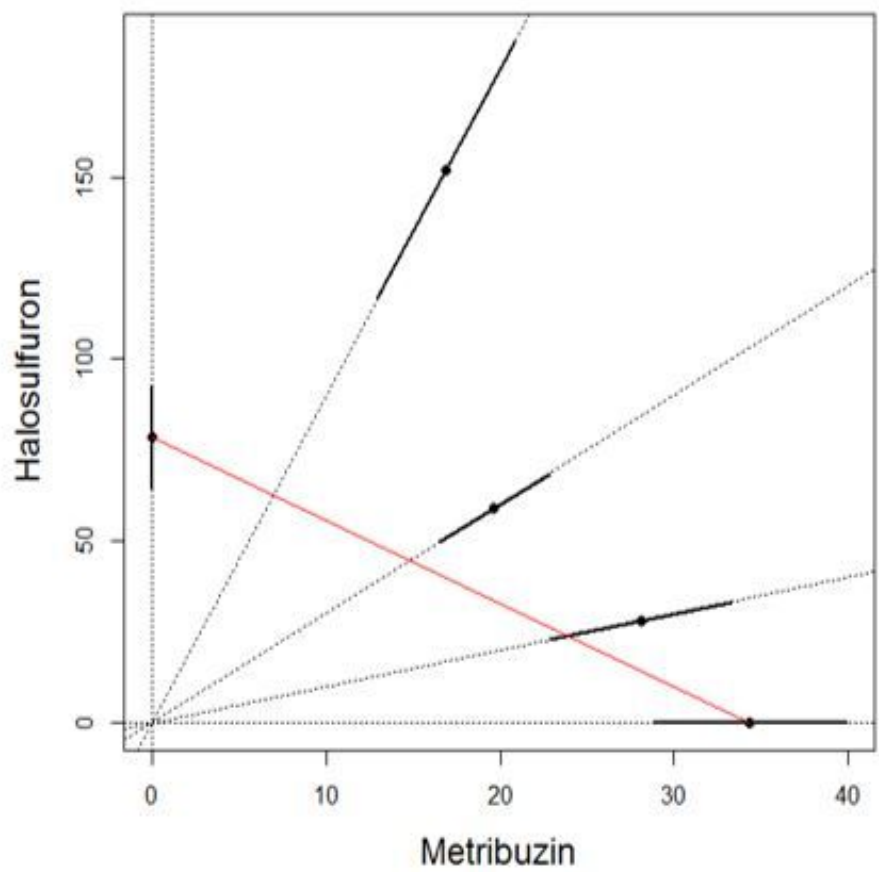

b1

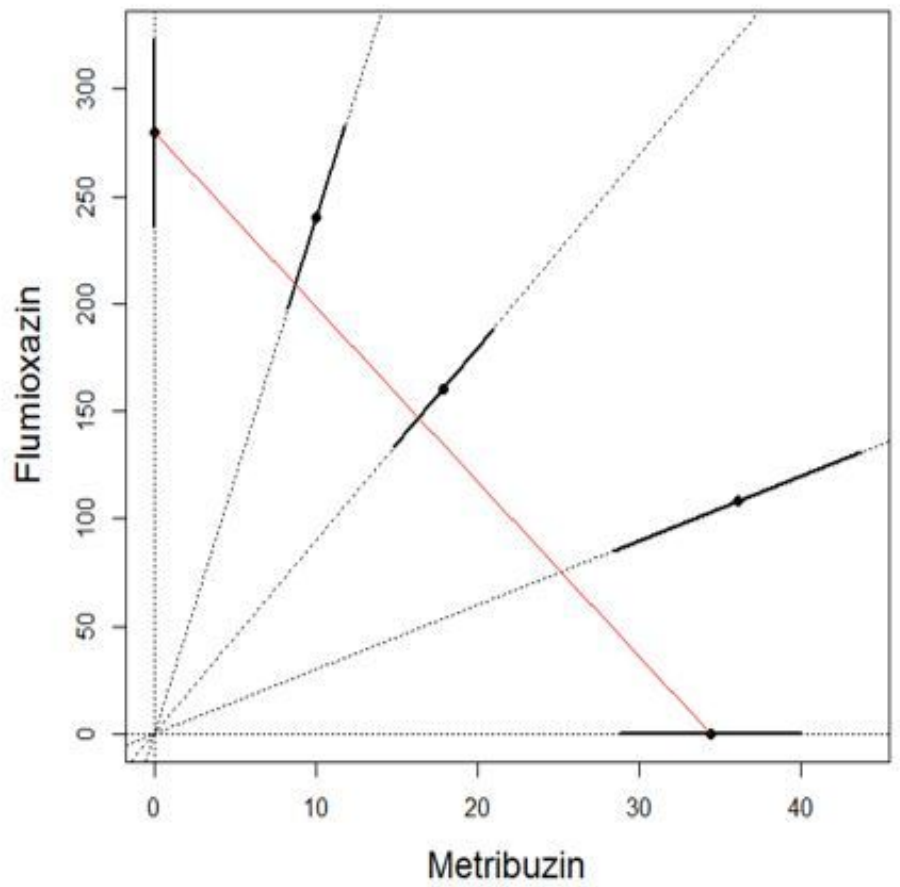

a2

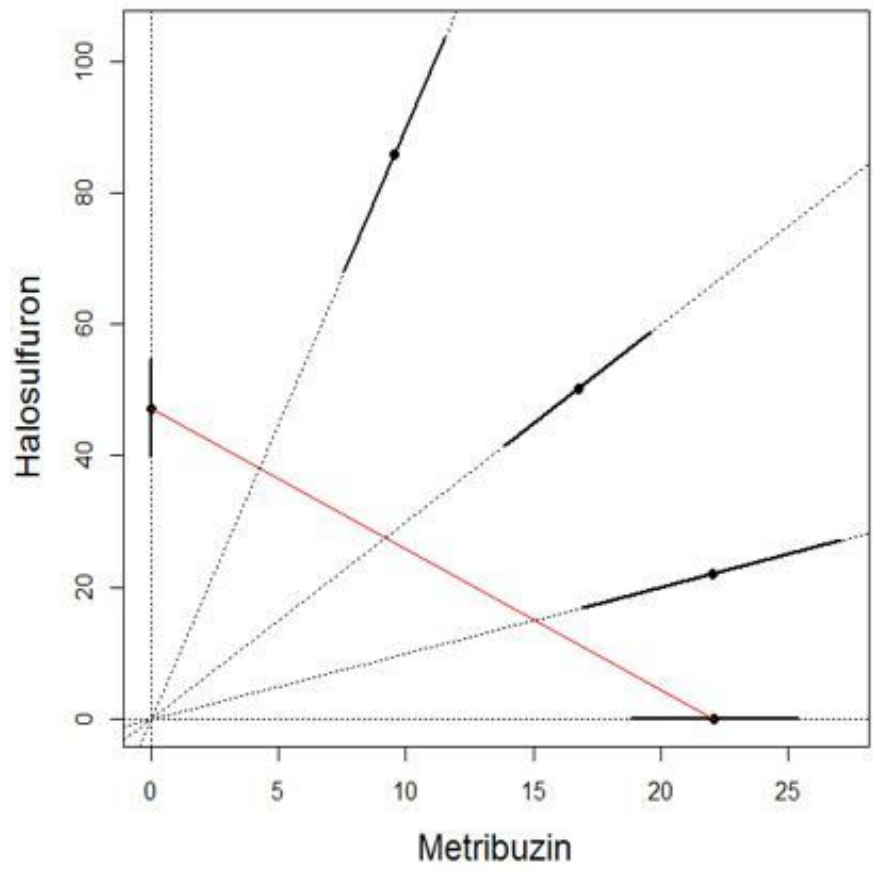

b2

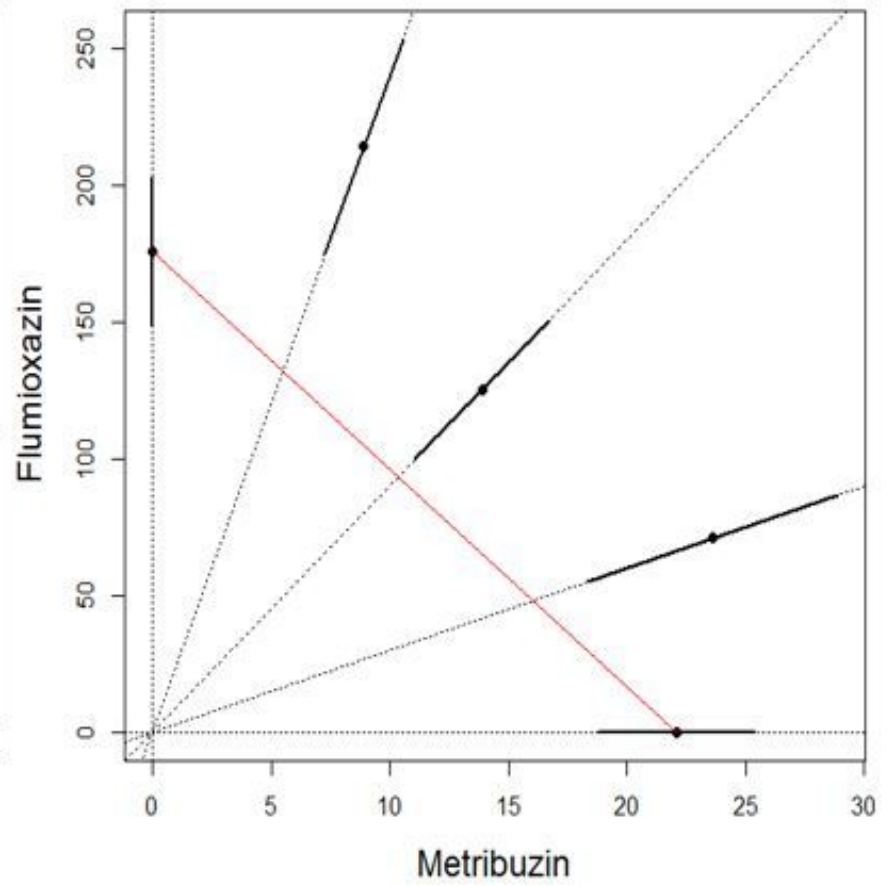

Figure 3

LC50 isobologram showing the toxicological interactions of metribuzin:halosulfuron (a) and metribuzin:flumioxazin (b) for a mortality rate of Eisenia fetida in second experiment of filter paper test at $24(1)$ and $48 \mathrm{~h}(2)$. The straight line of isobologram indicates additivity. The lines around the mixture points are $95 \%$ confidence intervals. 
a

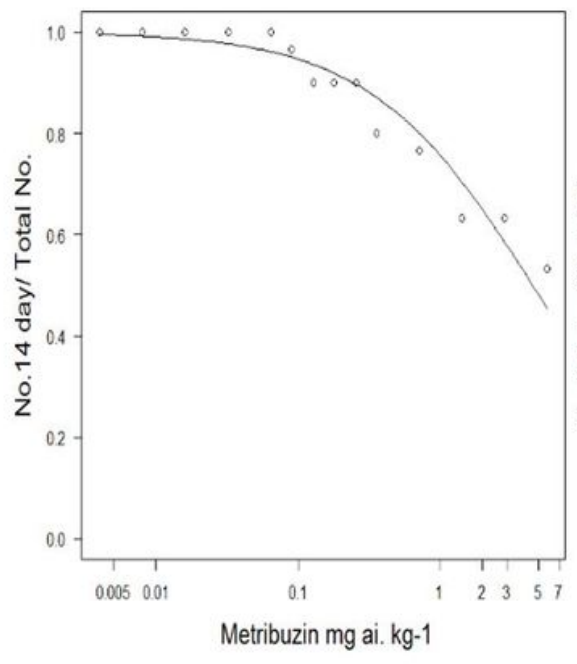

b

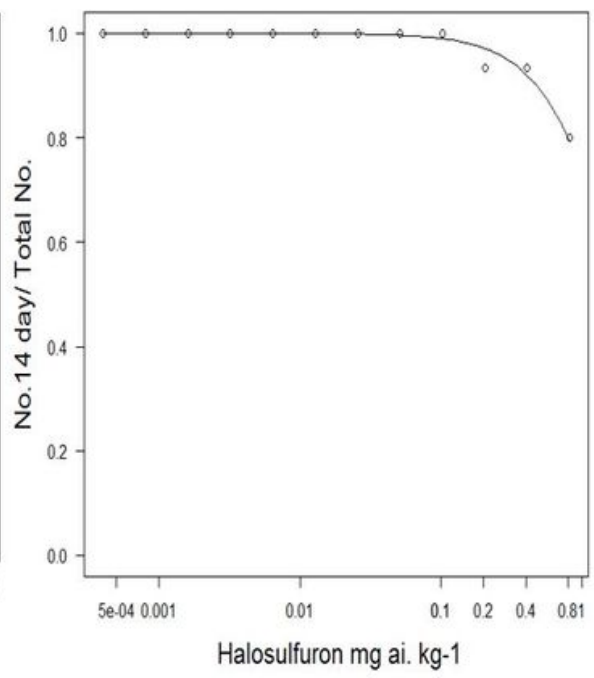

c

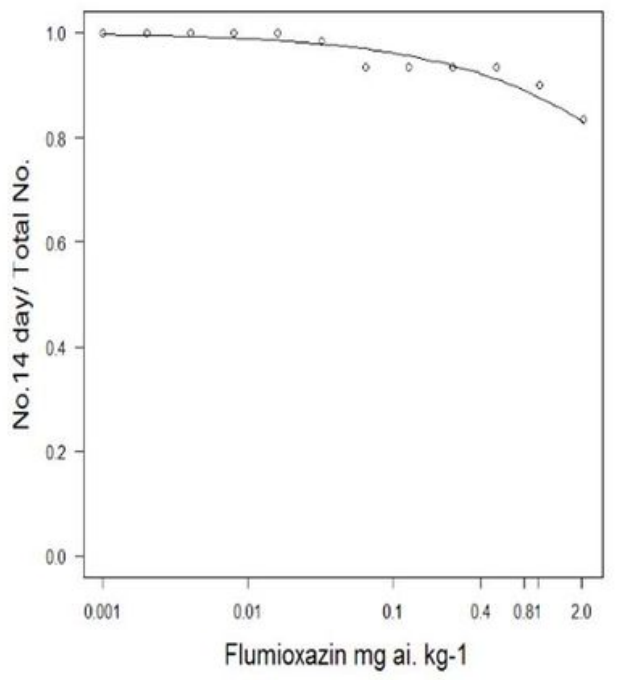

\section{Figure 4}

The effect of metribuzin (a), halosulfuron (b) and flumioxazin (c) on earthworm mortality at 14 days in artificial soil test 
al

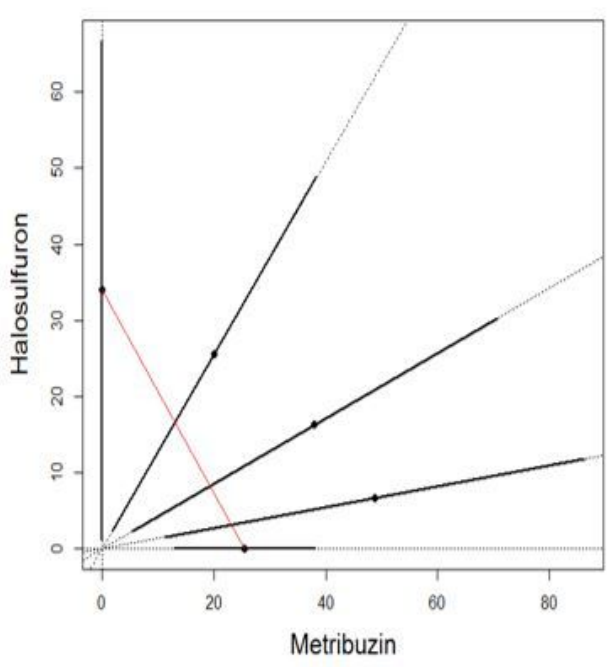

bl

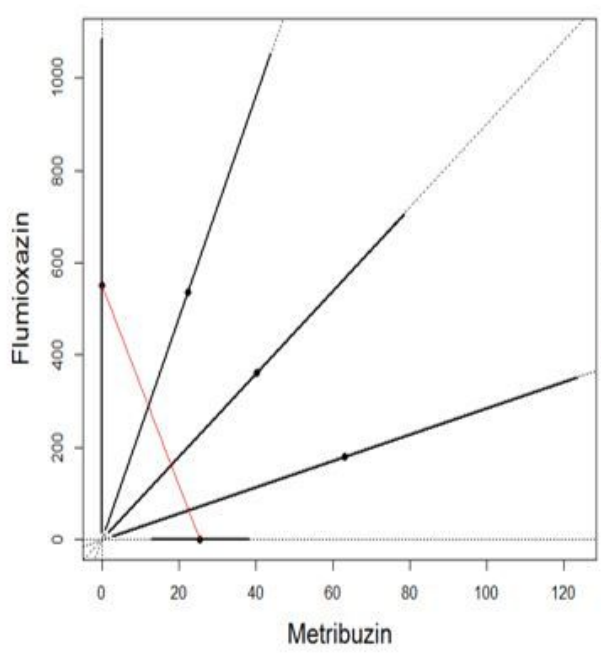

a2

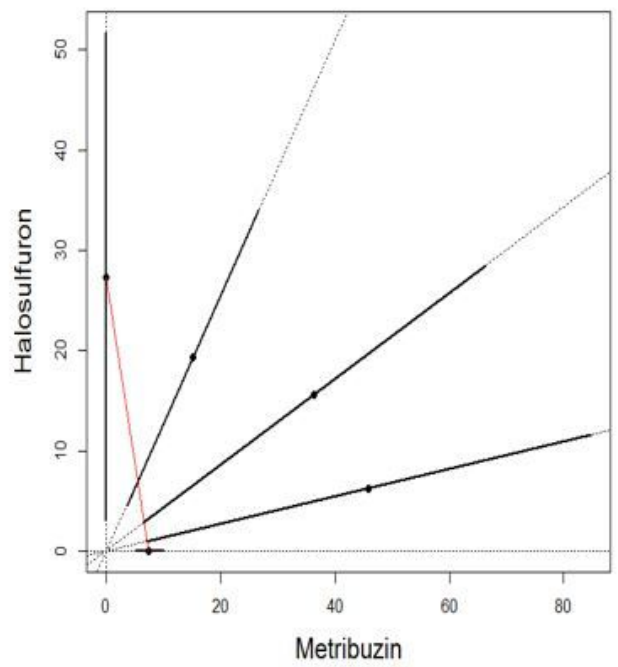

b2

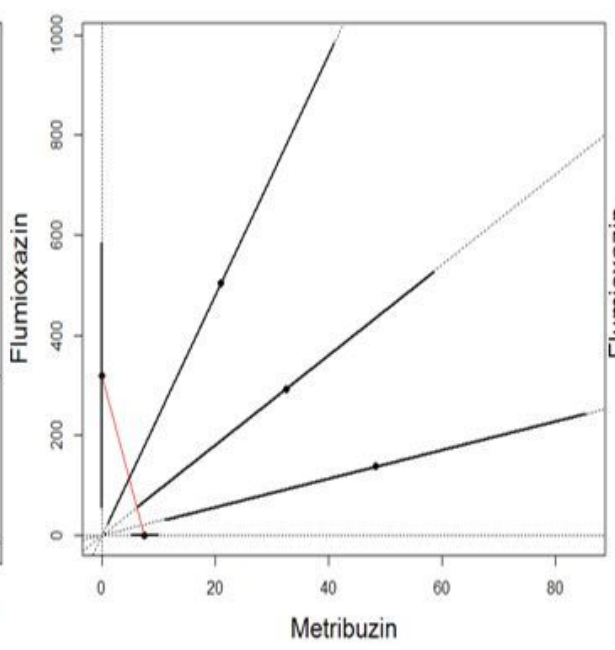

a3

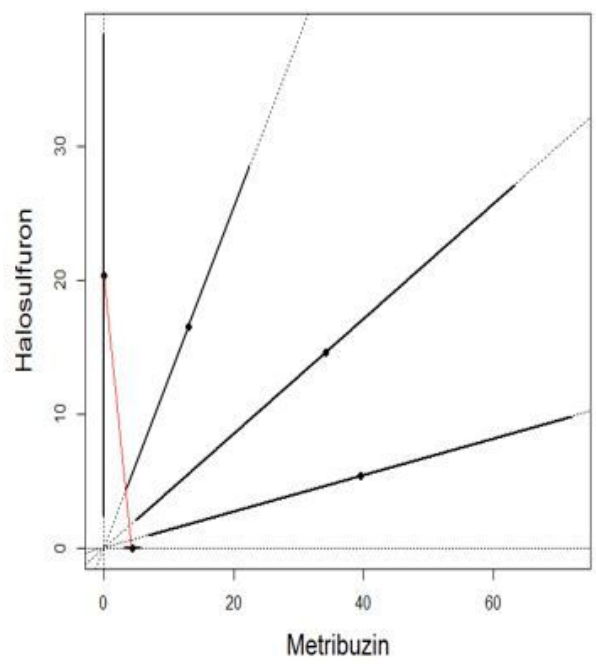

b3

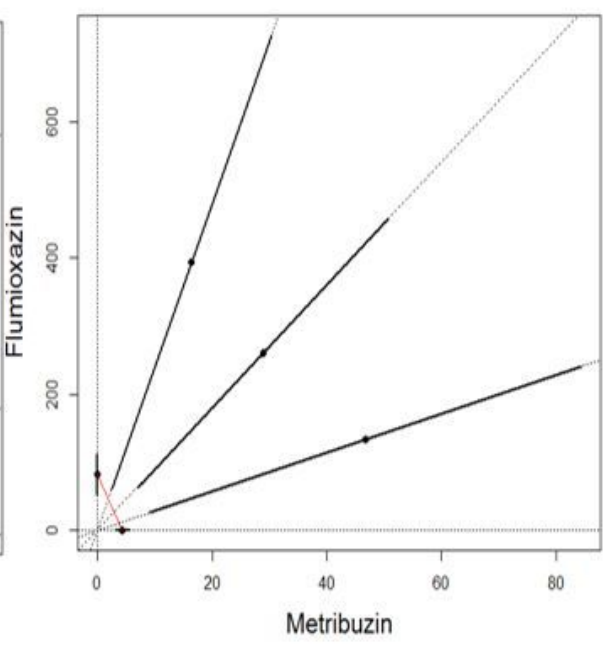

\section{Figure 5}

LC50 isobologram showing the toxicological interactions of metribuzin:halosulfuron (a) and metribuzin:flumioxazin (b) for a mortality rate of Eisenia fetida in first experiment of artificial soil test on $1(1), 7(2)$ and 14 day (3). The straight line of isobologram indicates additivity. The lines around the mixture points are $95 \%$ confidence intervals. 
al

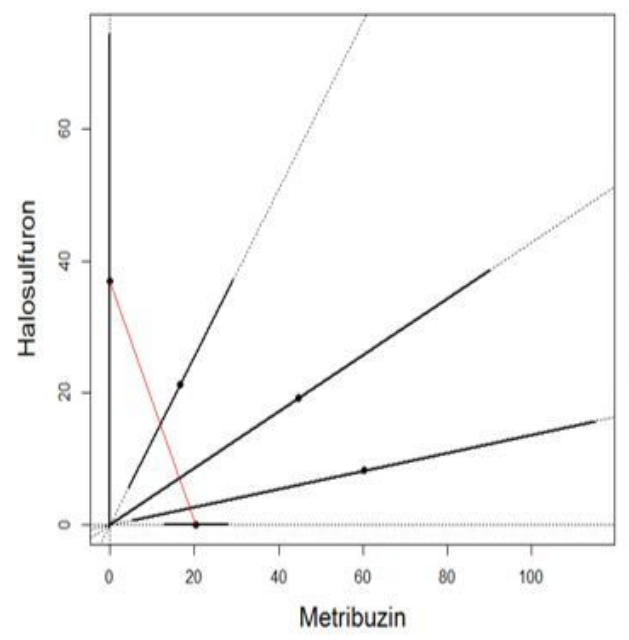

bl

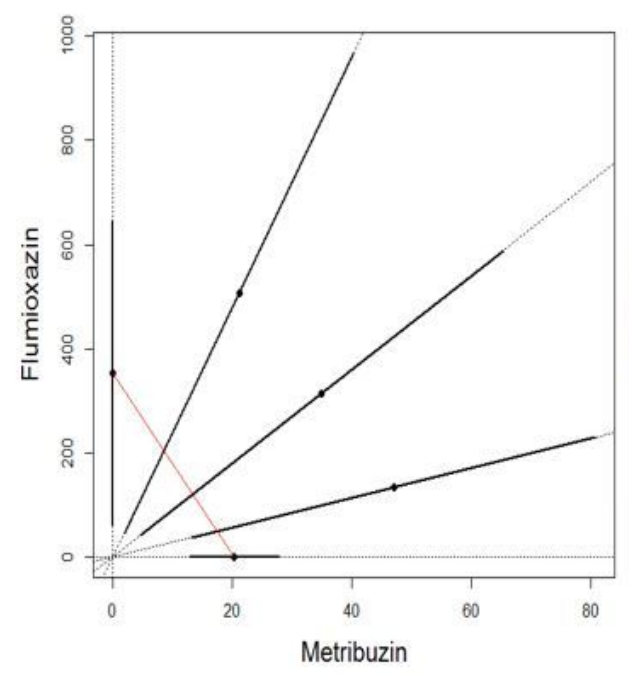

a2

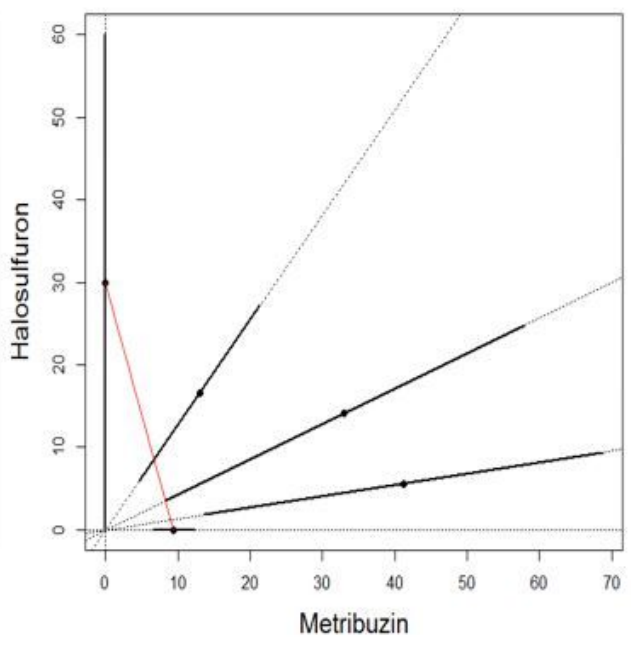

b2

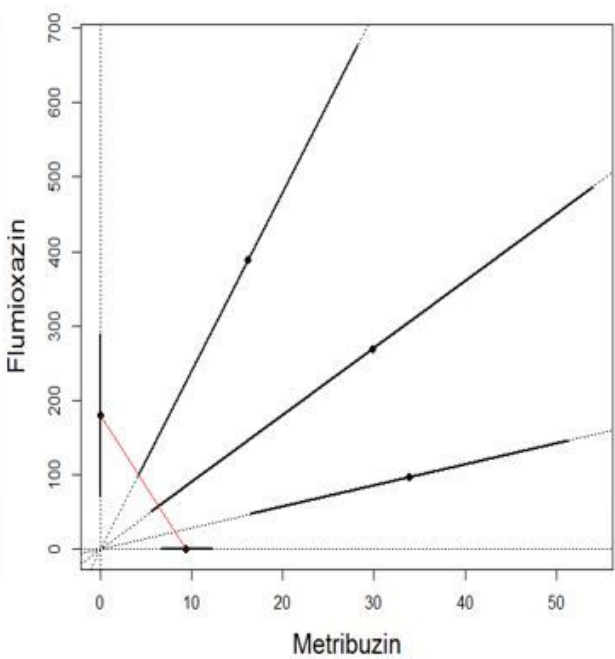

a3

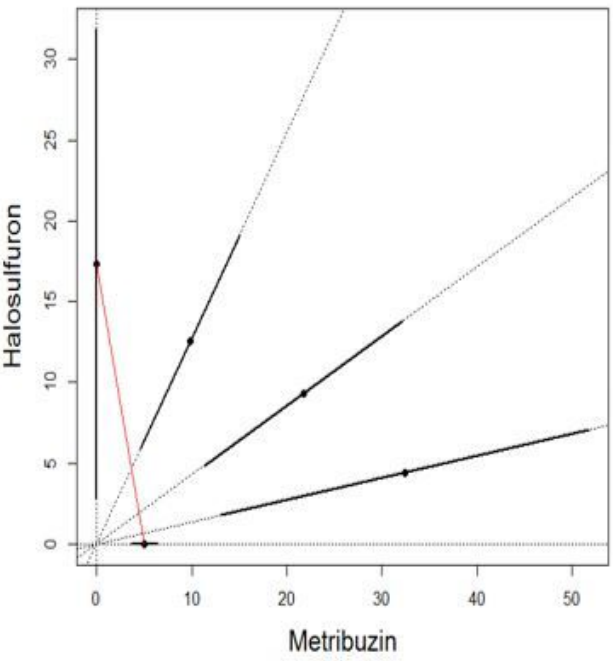

b3

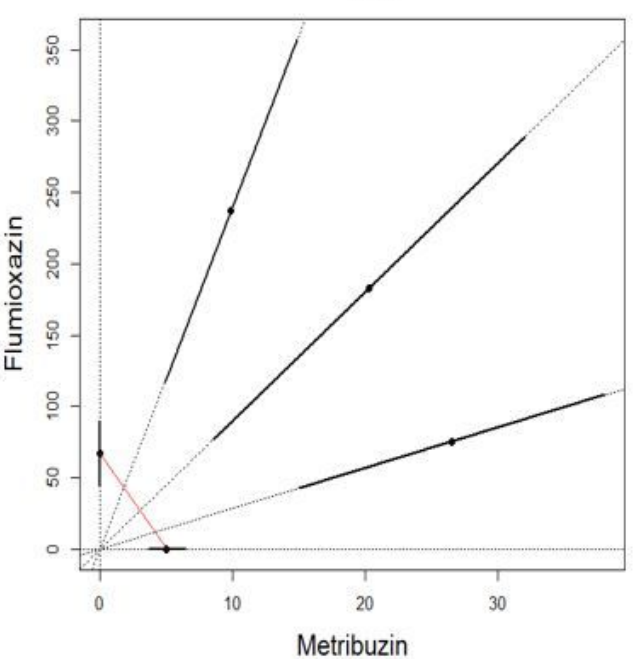

Figure 6

LC50 isobologram showing the toxicological interactions of metribuzin:halosulfuron (a) and metribuzin:flumioxazin (b) for a mortality rate of Eisenia fetida in second expriment of artificial soil test at 1(1), 7(2) and 14 (3) day. The straight line of isobologram indicates additivity. The lines around the mixture points are $95 \%$ confidence intervals. 


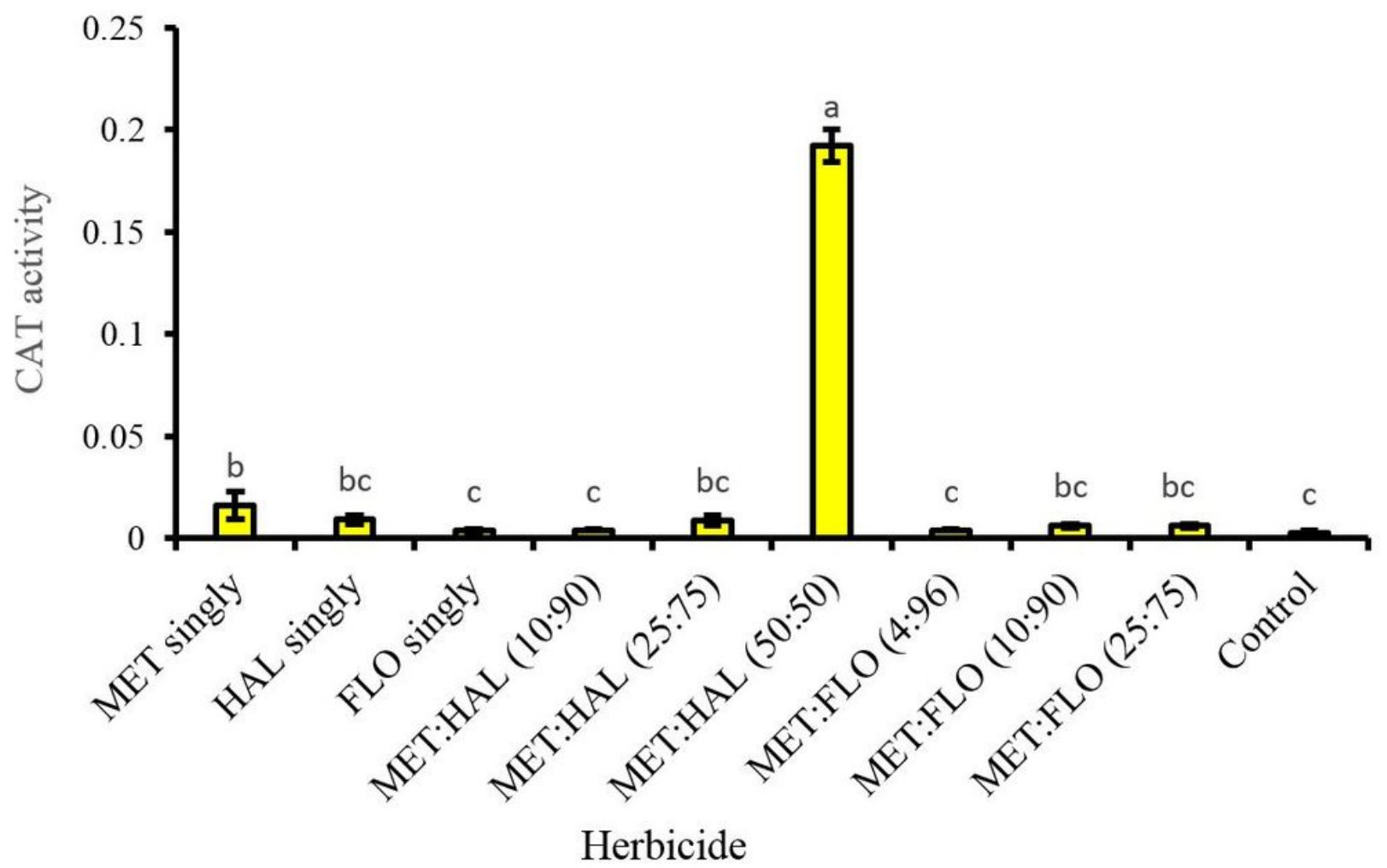

Figure 7

The effect of individual and combined herbicides on catalase (CAT) activity of earthworm 